\title{
The Significant Effect of Leadership and Conflict Management on Job Satisfaction
}

\author{
Sophia Anastasiou \\ Assistant Professor, \\ Faculty of Social Sciences, \\ University of Ioannina, Greece
}

DOI: https://doi.org/10.36941/ajis-2020-0107

Abstract

The purpose of this work is to present evidence which illustrate the significant effect of leadership and conflict management on employee satisfaction in a range of professions. Leadership and conflict management have a significant effect on job satisfaction. This is illustrated with examples of the interaction between these parameters in a range of professions. It is worth noting that a significant effect of leadership is exhibited in a range of different professional sectors and groups of employees, reflecting the universal value of leadership interacting with a wide range of parameters which may vary according to age, level of education, working conditions, cultural differences and employee expectations. Irrespective of the complexity and variety of determinant parameters, the effect of leadership and conflict management on job satisfaction has been widely exhibited in the reviewed data of the present analysis. Motivated and satisfied employees are a key in achieving organizational goals and leaders should take into account factors related to work performance, motivation and job satisfaction.

Keywords: Job satisfaction, leadership, conflict management, transformational, laissez-faire leadership

\section{Introduction}

The results of several research studies indicate that job satisfaction and leadership are important human resource management issues (Moslehpour et al., 2018). Leadership and motivation are inextricably linked (Afshinpour, 2014).

Leadership has been the subject of research and study for many years. Several theories have been developed and various interpretations have been given according to the point of view they are examined (Hollander, 1985; Bass, 1990; Mullins, 2007). The concept of leadership may have an arbitrary and subjective meaning and definition (Yulk, 1999; Leithwood, 2012; Manreka, 2015). It can be defined as the process where an individual influences attitudes and behaviors, encourages, inspires, motivates and energizes employees towards common goals (Evans, 1998; Northouse, 2018).

A successful leader will direct and lead to specific goals and has to ensure that all employees are committed towards these goals taking into account that differences in the performance, expectations and needs of individual employees may vary. A leader who can successfully address, inspire and activate all employees can create an environment that motivates all members to achieve the set goals through building trust, respect, motivation and satisfaction and being able to reach a consensus in the overall organizational objectives. It, therefore, means that the focus of the leader should be on the needs of all employees. Employees may be satisfied by a combination of intrinsic and extrinsic characteristics of 
their job. Leadership can help to increase the level of satisfaction received by extrinsic characteristics, by improving for example the communication and collaboration with employees. Employees feel that their views and needs are heard and addressed and can place their trust in the leader who exhibits the ability to solve issues and set higher goals efficiently (Ross \& Gray, 2006; Al Rahbi et al., 2017).

There are several leadership styles practiced by leaders. In achieving the success and growth of their organization, leaders must adapt and respond to fast-changing working conditions and social structures, organizational and employee expectations (Pongpearchan, 2014). In fact, leadership can be one of the most crucial factors which can determine the success or failure of any organization (Blair, 2018). Leaders may use a range of methods and styles but the level of success or failure they will achieve may be predetermined by this choice (Ross \& Gray, 2006).

The present analysis will be focused on the Transformational and Transactional leadership styles as there is a plethora of empirical evidence and research which indicate the popularity of these two leadership styles in various sectors and professions (Bass et al., 2003; Rajnandini \& Ethlyn, 2004; Walumbwa et al., 2005; Boamah et al., 2018).

Transformational leadership has been a subject of study and research for a long time (Guilford, 2018). Several studies indicate a positive relationship between transformational leadership and employee motivation (Northouse, 2018). Transformational leaders can motive people to desire change, desire to improve and increase their effectiveness and their job satisfaction. A transformational leader is expected to assess and satisfy the motives of individuals, values each one of them and their contributions to the success of their organization. As a result, transformational leadership style is frequently associated with improved work climate, commitment, effectiveness and employee job satisfaction (Jovanovica \& Ciricb, 2016).

There are three primary and essential functions of a transformational leadership style. The first function is about addressing the needs of employees, empowering and inspiring followers to achieve lasting success. The second function is to lead charismatically, cultivate trust and instill confidence and pride in belonging to the team. The third and final function is to intellectually produce followers who have similar skills (Castanheira \& Costa, 2011). By adopting this model, a leader can create a sustainable model of leadership. Transformational school leaders for example, are open to new ideas and flexible enough to implement new ways of teaching (Northouse, 2018).

Several theories of leadership have been developed over the past, with their own characteristics. Main theories that have emerged include: great man theory, trait theory, behavioral theory, process leadership theory, contingency theory, strategic leadership, transactional, transformational and laissez faire leadership. Leadership style is an important parameter of human resources management, with potentially significant indirect effects on employee work performance and job satisfaction (Anastasiou \& Garametsi, 2020).

Leadership is a crucial organizational parameter for motivating and satisfying employees and achieving organizational goals (Howell \& Avolio, 2013) and organisations should take into account the factors related to work performance, motivation and job satisfaction.

Job satisfaction can be defined as an affective or emotional state response towards various aspects of an individual's work (Ellickson \& Logsdon, 2001) that may influence various work aspects such as productivity, efficiency, absenteeism and employee turnover rates (Hyz, 2010; Abualrub \& Alghamdi, 2012). The various components of job satisfaction can be grouped into intrinsic and extrinsic job characteristics (Bektas, 2017); intrinsic parameters in terms of individuals' attitudes towards their jobs, while extrinsic parameters are related with work environment parameters such as supervisors, fellow workers, remuneration.

Employee commitment and satisfaction are affected by several extrinsic and intrinsic parameters, including personality traits, working conditions, social and economic factors and leadership (Anastasiou \& Papakonstantinou, 2014; Aga et al, 2016; Anastasiou \& Belios, 2020). Relevant research on job satisfaction on several professional sectors (Shann, 1998; Koustelios, 2001; Anastasiou \& Papakostantinou, 2014; Zopiatis et al., 2014; García-Chas et al., 2016; Kim, 2018; Jameel \& Ahmed, 2019) has identified a variety of 'internal' and 'external' factors that influence employee job satisfaction 
/ dissatisfaction and motivation: (i) individual factors, such as: gender, age, marital status, number of children and work experience; (ii) factors relating to the actual work, autonomy and independence; (iii) organisational factors related to work environment such as: leadership, supervision, support, facilities, infrastructure, organizational culture, participation in decision making, promotion prospects, etc.; (iv) factors related to the wider social context and the state such as the wider social and economic changes. The ttheoretical framework of the present analysis is graphically presented in Figure 1.

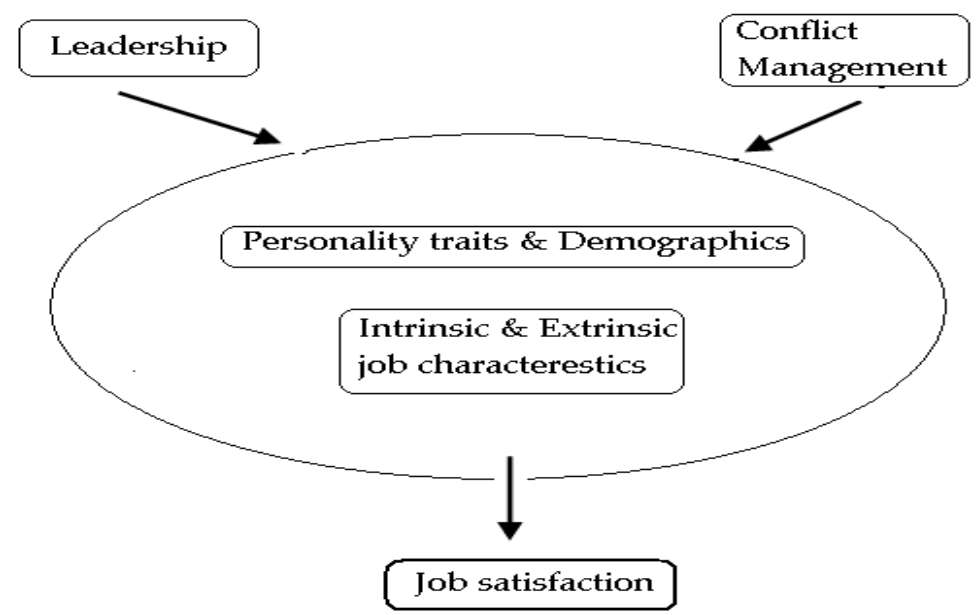

Figure 1. Theoretical framework of the present analysis. Leadership and Conflict management have a significant effect on employee job satisfaction. The effect may vary according to personality traits and demographics.

The purpose of this work is to present evidence which illustrate the significant effect of leadership and conflict management on employee satisfaction in a range of professions.

\section{The Relationship between Leadership and Conflict Management Traits}

Leaders are expected to exhibit traits which will encourage the communication between school, students, teachers, parents and other stakeholders (Sosik et al., 2016). A successful leader can motivate followers in achieving a set of goals (Howell, \& Avolio, 2013). There is evidence to suggest a significant correlation between leadership styles, conflict management style and job satisfaction in a range of professional sectors (Blair, 2018; Boamah et al., 2018).

Leaders may adopt different styles according to their personality traits, experience and management skills (Dumi \& Sinaj, 2013; Kaimenyi, 2014). There is a range of leadership traits which can be grouped according to their characteristics. According to Bass et al. (2003), different leadership styles include: transformational leadership, transactional leadership and passive leadership or laissez-faire leadership style.

Leaders are faced with challenging issues in a range of their tasks. A particular issue which leaders may face is workplace conflict. There is a need for leaders to understand the variety of approaches used in managing conflict by developing high competence in all conflict resolution areas so as to effectively manage their organization (Wanjiru, 2019). The various leadership styles should ensure that leaders use the best conflict management strategies in defining and determining the nature of conflicts as they try coping with them. 


\section{Transformational Leadership and Conflict Management}

Leadership style has a significant influence on conflict management. A transformational leader can help conflicting groups work together towards their common goals. He/she achieves this by providing encouragement and support, creating an environment that releases tensions and professionally handles disruptive behavior. Leaders who perceive themselves as transformational leaders adopt collaboration as the best and most frequent strategy of conflict management. Transformational leadership tends to encourage flexibility and creativity with an emphasis on critically questioning the set policies, evaluating strategies and gain effective performance (Tengi et al, 2017). Transformational leaders focus on future, which gives them the ability to value highly innovation and creativity. They create a synergistic environment that motivates and enhances collaboration towards change.

Leaders set the tone for conflict management through their leadership styles. Work experience and personality traits of a leader can contribute in the success and choices of strategies employed during conflict management. Experienced transformational leaders may select conflict management strategies which ensure that relationships are not destroyed and relations with other members of the staff who are involved in a particular conflict are affected negatively (Neves et al, 2019). A great leader should recognize which conflict management qualities and skills or solutions' strategy are most suitable for each case. There are a variety of strategies that leaders can use to deal with. The five approaches are Smoothing Accommodating, Forcing-Competing, Avoidance, Compromising and Collaboration Integration (Marquis, 2015; Saiti, 2015).

Leaders can use various resolution mechanisms to resolve conflicts at work. Leaders' effectiveness to use conflict resolution approaches enhance their awareness of highlighting various conflicting situations that, in turn, lead to the best way of solving differences among people (Wanjiru, 2019). Successful conflict management leaders can benefit by understanding the root causes of conflicts and select the best approach that will give them an amicable solution.

Conflict at work can arise as a result of various disputes at a personal level between employees, groups and managers (Wanjiru, 2019). These conflicts can be managed by a leader who embrace important conflict management strategies to bring them to an end and create peaceful co-existence and resolution. Ideally, leaders should be effective in reaching organizational goals, motivate their employees and resolve conflicts. There is some evidence to suggest a negative correlation between conflict at work and job satisfaction. High levels of conflict can be associated with lower level of job satisfaction. For example, a correlation between conflict at work and the effectiveness of leaders and employees has been reflected on a negative correlation between conflict level and job satisfaction (Khun-inkeeree et al., 2019). For example, Chandolia \& Anastasiou (2020) have reported that compared to the laissez-faire school leadership style, transformational leadership style was associated with low level of conflict at schools. In the same manner, the effect of different conflict management styles was reflected on teachers' satisfaction. In their study, Chandolia \& Anastasiou (2020) concluded that in most cases, leadership traits have a significant effect on teachers as illustrated graphically in Figure 2. In the same manner, a significant effect of leadership on job satisfaction can be seen in a range of professions, including the academia, nurses, civil service, manufacturing and construction workers (Rad \& Yarmohammadian, 2006; Leet, 2008; AbuAlRub \& Alghamdi, 2012; Madlock, 2013). It can be concluded that the significant effect of leadership on employee job satisfaction, commitment and efficiency is exhibited in a wide range of professions (Lee et al., 2008; Madlock et al., 2013; Anastasiou \& Garametsi, 2020).

The effect of leadership on job satisfaction has been frequently documented using correlation analysis between leadership traits and job satisfaction. For example, job satisfaction correlated well with leadership traits in several professions and the coefficient $\mathrm{r}$ exhibited values around 0.5 ( 0.45 in nurses) (Abuaalrub \& Alghamdi, 2012); 0.53 in various sectors (Rad \& Yarmohammadian, 2006); 0.57 in services, manufacturing, mining and construction (Lee, 2008) to 0.62 (Boamah et al., 2018) in hospitals. In several cases, a positive correlation between: (i) employee satisfaction and leadership traits and (ii) job satisfaction and effectiveness of employees was exhibited (Walumbwa et al. 2005; Chan et al., 2008; 
Hyz, 2010; Kaitelidou et al., 2012; Alonderiene. \& Majauskaite, 2016; Boamah et al., 2017).
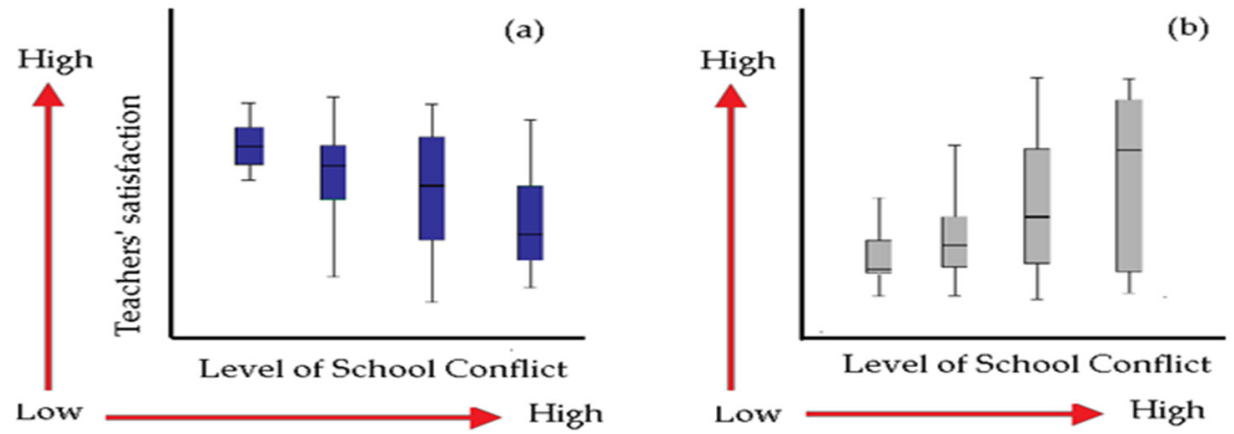

Figure 2. Level of school conflict and level of teachers' satisfaction with (a) Transformational, (b) Laissez-faire leadership style.

Source: Redrawn from Chandolia \& Anastasiou (2020).

For example, the correlation between conflict and teachers' satisfaction is modified according to different leadership styles (Figure 2). School conflict correlates with teacher satisfaction. A negative correlation was exhibited when leaders adopted Transformational leadership style while the reverse was exhibited in school units with a Laissez-faire leadership style adopted by school leaders. Similar results have been reported in other professional sectors (Rad \& Yarmohammadian, 2006; Lee, 2008; AbuAlRub \& Alghamdi, 2012; Madlock, 2013). In the same manner, Saiti (2007) investigated the effect of several exogenous parameters which can affect job satisfaction in elementary school teachers in Greece and concluded that leadership was one of the most important organizational parameters which can affect job satisfaction. Batiou \& Valkanos (2013), also observed that exogenous factors contributed in the job satisfaction of public services sector employees in Thessaloniki, Greece.

In addition to organizational factors, age may matter when it comes to the level of employee job satisfaction. Some studies have reported a positive effect of age on the level of job satisfaction (Figure 3), whereas other studies reported a negative effect (Figure 4) or no change in the level of job satisfaction with age (Clark et al., 1996; Hyz, 2010; Catania \& Randall, 2013; Karamanis et al., 2019; Anastasiou \& Belios, 2020). The effect of age may vary according to several parameters including personality traits, organisational parameters and demographics. Older employees may develop social skills which can enhance their ability to handle interpersonal conflicts (Anastasiou, 2020) or may exhibit higher level of job satisfaction compared to younger employees as they may enjoy higher salary or become more financially secure as they grow older (Lord \& Farrington, 2006; Anastasiou \& Belios, 2020). Employees may feel unhappy with their salary and other extrinsic job characteristics and this can affect their job satisfaction and motivation. For example, job security (Origo \& Pagani, 2009) may affect job satisfaction while older employees may or may not feel secure and this might change according to their employment sector and several economic parameters which can affect employment and economic growth at regional, national and global level.

Effective leaders may face challenging problems in their work which require a range of skills and personality traits. In times of tension and low trust at work place, conflict management skills are required to address and solve the different views and priorities between and within employees, groups and management. If ignored, conflict at work may increase the level of competition and hinder interpersonal relationships and team work spirit, resulting in reduced effectiveness and low job satisfaction (Kaitelidou et al., 2012). In spite of the potential negative effects of conflict at work, successful leaders may take advantage of the challenges and opportunities of conflict at work in 
engaging employees in a fruitful process of conflict management. In fact, effective conflict management can increase the level of communication, understanding and trust in an organization (Chan et al., 2008).

Leadership is a crucial element for the growth and success of an organization and a crucial parameter of job satisfaction, commitment and employee efficiency (Lee, 2008; Madlock, 2013; Anastasiou \& Garametsi, 2020). Effective leadership is characterised by motivating employees and achieving organizational goals (Cote, 2019). The level of employee motivation, commitment, efficiency and job satisfaction may vary according to leadership style and other organizational parameters (AbuAlRub \& Alghamdi, 2012).

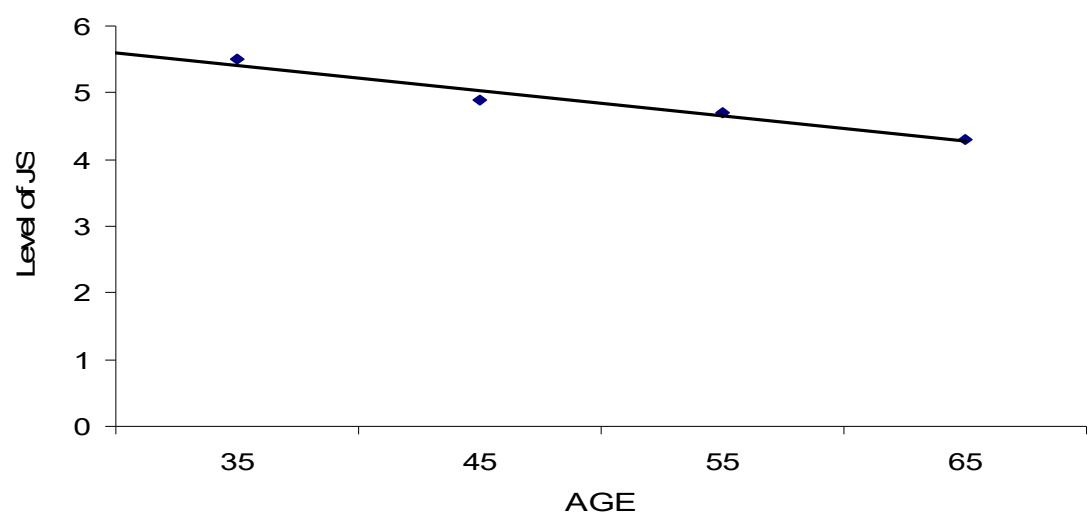

Figure 3. An example of a negative effect of age on job satisfaction. A regression analysis of Age and Job Satisfaction (JS) indicated that the level of JS may be reduced with age. The $\mathrm{R}^{2}$ for JS was 0.962 which suggests that the predictor Age accounts for $96.2 \%$ of the total variation in the dependent JS ( $\mathrm{F}$ $(1,3)=51.571, \mathrm{p}=0.0184)$.

Source: Recalculated and plotted using data from Anastasiou \& Garametsi (2020)

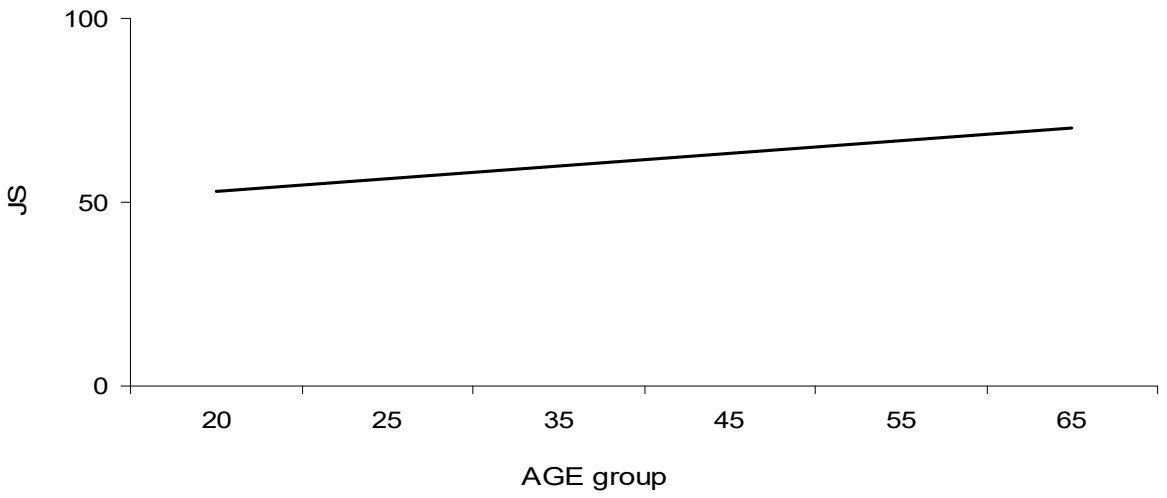

Figure 4. An example of a positive effect of age on job satisfaction. A regression analysis of Age and Job satisfaction (JS) indicated that the level of JS may be increased with age. The $\mathrm{R}^{2}$ for JS was 0.962 which suggests that the predictor AGE accounts for $96.2 \%$ of the total variation in the dependent JS $(\mathrm{F}(1,3)=51.571, \mathrm{p}=0.0184)$.

Source: Recalculated and plotted using data from Clark et al.,1996. 
The effect of leadership on job satisfaction can be modulated by a variety of parameters such as personality traits, employees' needs and organizational factors such as working conditions and salary (Bass, 2003; Ismail, et al. 2009; Anastasiou, \& Papakonstantinou, 2014; Aldridge \& Fraser, 2016; Moslehpour et al., 2018; Anastasiou \& Garametsi, 2020). In any event, the data reviewed in the present work indicate that leadership correlated well with satisfaction in several professions.

\section{Conclusion}

There are several parameters which can contribute to increased employee job satisfaction. The data reviewed in the present work provide some examples which illustrate the significant effect of leadership on job satisfaction. It is worth noting that the reviewed data were from different professional sectors and employee groups, reflecting the wide range of parameters which may vary according to age, level of education, working conditions, cultural differences and expectations. Irrespective of the variety of determinant parameters, the effect of leadership on conflict management and job satisfaction was widely exhibited in the reviewed data of the present analysis.

Leaders should be aware of above mentioned parameters related to conflict management and the potential mediating effect of conflict and leadership style on job satisfaction and commitment of employees.

\section{References}

AbuAlRub, R. F., \& Alghamdi, M. G. (2012). The impact of leadership styles on nurses' satisfaction and intention to stay among Saudi nurses. Journal of Nursing Management, 20(5), 668-678.

Afshinpour, S. (2014). Leadership Styles and Employee Satisfaction: A Correlation Study. Int. Lett. Soc. Humanist. Sci. ILSHS 2014, 16, 156-169.

Aga, D. A., Noorderhaven, N., \& Vallejo, B. (2016). Transformational leadership and project success: The mediating role of team-building. International Journal of Project Management, 34(5), 8o6-818.

Aldridge, J. M., \& Fraser, B. J. (2016). Teachers' views of their school climate and its relationship with teacher self-efficacy and job satisfaction. Learning Environments Research, 19(2), 291-307. https://doi.org/10.1007/s10984-015- 9198-x.

Alonderiene, R., \& Majauskaite, M. (2016). Leadership Style and Job Satisfaction in Higher Education Institutions. International Journal of Educational Management, 30(1), 140-164.

Al Rahbi, D., Khalid, K., \& Khan, M. (2017). The Effects of Leadership Styles on Team Motivation. Academy of Strategic Management Journal, 16(3), 1-14.

Anastasiou, S. (2020). The Moderating Effect of Age on Preschool Teachers' Trait Emotional Intelligence in Greece and Implications for Preschool Human Resources Management. International Journal of Education and Practice, 8(1), 26-36.

Anastasiou, S., \& Papakonstantinou, G. (2014). Greek high school teachers' views on principals' duties, activities and skills of effective school principals supporting and improving education. International Journal of Management in Education, 9(3), 340-358.

Anastasiou, S. \& Belios, E. (2020). Effect of Age on Job Satisfaction and Emotional Exhaustion of Primary School Teachers in Greece. Eur. J. Investig. Health Psychol. Educ. 10, 644-655.

Anastasiou, S. \& Garametsi, V. (2020). "Perceived leadership style and job satisfaction of teachers in Public and Private Schools". International Journal of Management in Education (in press). Doi: 10.1504/IJMIE.2021.10029495.

Anastasiou, S., \& Papagianni, A. (2020). Parents', Teachers' and Principals' Views on Parental Involvement in Secondary Education Schools in Greece. Education Sciences, 10(3), 69.

Bass, B.M. (1990). Bass and Stogdill's Handbook of leadership: Theory, research, and managerial applications ( $3^{\text {rd }}$ edition). New York: Free Press.

Bass, B. M., Avolio, B. J., Jung, D. I., \& Berson, Y. (2003). Predicting unit performance by assessing transformational and transactional leadership. Journal of Applied Psychology, 88(2), 207-218. doi:10.1037/oo21-9010.88.2.207.

Batiou, V. \& E. Valkanos. (2013). Job satisfaction of Public Administrative Personnel in Greece. International Journal of Academic Research in Business and Social Sciences, 3(11):239-248.

Bektas, C. (2017). Explanation of intrinsic and extrinsic job satisfaction via mirror model. Business \& Management Studies: An International Journal., 5(3), 627-639. doi:10.15295/bmij.v5i3.118. 
Blair, E. (2018). Transformative teacher leadership education is inclusive. Responding to Learner Diversity and Learning Difficulties, 417.

Boamah, S. A., Laschinger, H. K. S., Wong, C., \& Clarke, S. (2018). Effect of transformational leadership on job satisfaction and patient safety outcomes. Nursing outlook, 66(2), 180-189.

Castanheira, P. \& Costa, J. A. (2011). In search of transformational leadership: A (Meta) analysis focused on the Portuguese reality. Procedia Social and Behavioural Sciences, 15 (2011), 2012-2015.

Catania, G., \& Randall, R. (2013). The relationship between age and intrinsic and extrinsic motivation in workers in a Maltese cultural context. International Journal of Arts \& Sciences, 6(2), 31-45.

Chandolia, E. \& Anastasiou, S. (2020). Leadership and conflict management style are associated with the effectiveness of school conflict management in the region of Epirus, NW Greece. European Journal of Investigation in Health, Psychology and Education, 10(1), 455-468. https://doi:10.339o/ejihpe10010034.

Chan, K. W., Huang, X., \& Ng, P. M. (2008). Managers' conflict management styles and employee attitudinal outcomes: The mediating role of trust. Asia Pacific Journal of Management, 25(2), 277-295.

Clark, A., Oswald, A., \& Warr, P. (1996). Is job satisfaction U-shaped in age? Journal of occupational and organizational psychology, 69(1), 57-81.

Cote, R. (2019). Motivating Multigenerational Employees: Is There a Difference? Journal of Leadership, Accountability and Ethics, 16(2), 15-29.

Day, C., Gu, Q., \& Sammons, P. (2016). The impact of leadership on student outcomes: How successful school leaders use transformational and instructional strategies to make a difference. Educational Administration Quarterly, $52(2), 221-258$.

Dumi, A. R., \& Sinaj, Z. (2013). "Leadership in the Cross-Cultural Context". Analyze of Rational Theories and Aspects of Leader Role in Long Term Characterized. The Observation of Behavior Effects in Albania. Academic Journal of Interdisciplinary Studies, 2(1), 59. Retrieved from http://www.richtmann.org/journal/index.php/ajis/article/view/62.

Ellickson M.C. \& Logsdon, K. (2001). Determinants of job satisfaction of municipal government employees. Public Personnel Management, 31,3, (2001), 343-358.

Evans, L. (1998). Teacher, morale, job satisfaction and motivation. Thousand Oaks, C.A.: Sage.

Guilford, C. A. (2018). Effective leadership practices and reading achievement at the secondary level. Doctoral Dissertation, Delaware State University.

García-Chas, R., Neira-Fontela, E., \& Varela-Neira, C. (2016). High-performance work systems and job satisfaction: a multilevel model. Journal of Managerial Psychology, 31(2), 451-466.

Khun-inkeeree, H., Jamaluddin, M., Omar-Fauzee, M. S., Kasa, M. D., Husin, F., Sofian, F. N. R. M., \& Tulyakul, S. (2019). Relationship between Conflict Management Styles and Job Satisfaction of Private Islamic Secondary School Teachers. Frontiers in Education Technology 2(4), 255-272. doi: 10.22158/fet. v2n4p255.

Hollander, E. P. (1985). "Leadership and power". In G. Lindzey \& E. Aronson (eds.) The handbook of social psychology (pp. 485-537). New York: Random House.

Howell, J. M., \& Avolio, B. J. (2013). Transformational leadership, transactional leadership, locus of control, and support for innovation: Key predictors of consolidated business unit performance. Journal of Applied Psychology, 7, 891-902.

Hyz, A. (2010). Job Satisfaction and Employee Performance of Greek Banking Staff: An Empirical Investigation. Folia Oeconomica, 239, 85-96.

Ismail, A.; Ismail, Y.; Ibrahim, Z.; Leng, C.; Kiong, P. (2009). Relationship between pay level, pay structure and job commitment in Malaysian public community college: The mediation role of distributive justice. South East Asian J. Manag. 3, 99-111.

Jameel, A. S., \& Ahmed, A. R. (2019). The effect of Transformational Leadership on Job Satisfaction among Academic Staff. In Proceedings of the 34th International Business Information Management Association: 13-14 November 2019, Madrid, Spain; IBIMA.

Jovanovica, D. \& Ciricb, M. (2016). Benefits of transformational leadership in the context of education. The European Proceedings of Social \& Behavioral Sciences EpSBS.

Kaimenyi, C. K. (2014). The Influence of Conflict Management Styles on Leadership Approaches. Journal of Business and Management, 16 (9) Sept., 55-59.

Kaitelidou, D., Kontogianni, A., Galanis, P., Siskou, O., Mallidou, A., Pavlakis, A., \& Liaropoulos, L. (2012). Conflict management and job satisfaction in pediatric hospitals in Greece. Journal of nursing management, 20(4), 571-578.

Karamanis, K., Arnis, N., \& Pappa, P. (2019). Impact of working environment on job satisfaction. Theoretical and Empirical Researches in Urban Management, 14(3), 5-21.

Kim, H. (2018). The Effect of Personal Characteristics of SW Industry Employees on Job Satisfaction-Intrinsic Rewards and Extrinsic Rewards Regulating Effect. Journal of the Korea Society of Digital Industry and Information Management, 14(2), 117-131. 
Koustelios, A. D. (2001). Personal Characteristics and Job Satisfaction of Greek Teachers. The International Journal of Educational Management, 15(7), 354-358.

Lee, K. L. (2008). An examination between the relationships of conflict management styles and employees' satisfaction. International Journal of Business and Management, 3(9), 11-25.

Leithwood, K. (2012). The move towards transformational leadership. Educational Leadership, 49(5), 8-9.

Lord, R. L. \& Farrington, P. A. (2006). Age-related differences in the motivation of knowledge workers. Engineering Management Journal, 18 (3), 20-26.

Northouse, P. G. (2018). Leadership: Theory and practice. Sage publications.

Manreka, A. (2015). Concept of Teacher Leaders and Creation of Friendly Climate in the Classroom: In Secondary Education (High School), in Albania. Academic Journal of Interdisciplinary Studies, 4(3 S1), 322. Retrieved from http://www.richtmann.org/journal/index.php/ajis/article/view/8390

Madlock, P. E. (2013). The influence of conflict management, leadership, and communication on employee job satisfaction. Human Communication, 15, 121-138.

Marquis, B. L., \& Huston, C. J. (2015). Leadership roles and management functions in nursing: Theory and application. Lippincott Williams \& Wilkins.

Moslehpour, M., Altantsetseg, P., ltantsetseg, A. Mou, M., Wong, WK. (2018). Organizational Climate and Work Style: The Missing Links for Sustainability of Leadership and Satisfied Employees. Sustainability 11(1),125.

Mullins, L.J. (2007). Management and Organizational Behavior (7th edition). Harlow: FT/Prentice Hall.

Neves, L. G., \& Coimbra, J. L. (2019). Evidence of the Validity of the Internal Structure of the Ethical, Transformational, and Moral Leadership Scale in an Educational Portuguese Context. Paidéia (Ribeirão Preto), 29.

Origo, F. \& Pagani, L. (2009). Flexicurity and job satisfaction in Europe: The importance of perceived and actual job stability for well-being at work. Labor Economics, 16(5), 547-555.

Pongpearchan, P. (2016). Effect of Transformational Leadership and High Performance Work System on Job Motivation and Task Performance: Empirical Evidence from Business Schools of Thailand Universities. Journal of Business and Retail Management Research, 10(3), 93-105.

Rad, A. M. M., \& Yarmohammadian, M. H. (2006). A study of relationship between managers' leadership style and employees' job satisfaction. Leadership in Health Services, 19(2), 11-28.

Rajnandini, P., \& Ethlyn, A. W. (2004). Transformational leadership, self-efficacy, group cohesiveness, commitment, and performance. Journal of Organizational Change Management, 17(2), 144-159.

Ross, J. A. \& Gray, P. (2006). Transformational leadership and teacher commitment to organizational values: the mediating effects of collective teacher efficacy. School Effectiveness and School Improvement, 17(2), 179- 201.

Saiti, A. (2007). Main Factors of Job Satisfaction among Primary School Educators: Factor Analysis of the Greek Reality. Management in Education, 21(2),28-32. https://doi.org/10.1177/0892020607076658 14.

Saiti, A. (2015). Conflicts in schools, conflict management styles and the role of the school leader: A study of Greek primary school educators. Educational Management Administration E Leadership, 43(4), 582-609.

Shann, M. (1998). Professional commitment and satisfaction among teachers in urban middle schools. The Journal of Educational Research, 92, 67-73.

Sosik, J. J., Avolio, B. J., \& Kahai, S.S. (2016). The impact of leadership style and anonymity on group potency and effectiveness in a GDSS environment. Journal of Applied Psychology, 82, 89-103.

Tengi, M. L., Mansor, M., \& Hashim, Z. (2017). A Review Theory of Transformational Leadership for School. International Journal of Academic Research in Business and Social Sciences, 7(3), 792-799.

Yukl, G. (1999). An evaluation of conceptual weaknesses in transformational and charismatic leadership theories. Leadership Quarterly, 10, 285-305.

Walumbwa, F. O., Orwa, B., Wang, P., \& Lawler, J. J. (2005). Transformational leadership, organizational commitment, and job satisfaction: A comparative study of Kenyan and U.S. financial firms. Human Resource Development Quarterly, 16(2),235-256.

Wanjiru, J. (2019). School leadership and post-conflict education: How can their roles in developing inclusive practices in post-conflict schooling be understood and conceptualized? Educational Management Administration E Leadership. doi.org/10.1177/1741143219884693.

Zopiatis, A., Constanti, P., \& Theocharous, A. L. (2014). Job involvement, commitment, satisfaction and turnover: Evidence from hotel employees in Cyprus. Tourism Management, 41, 129-140. 